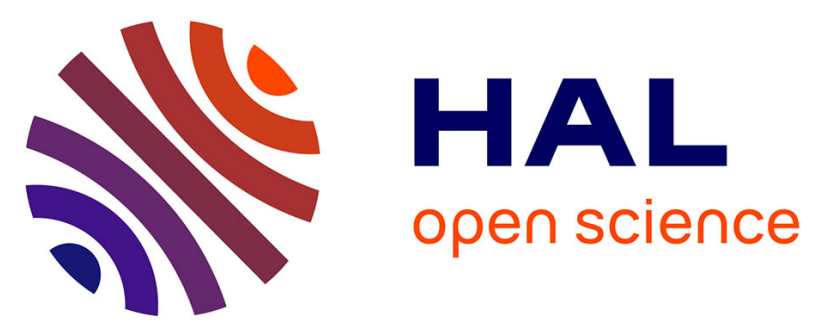

\title{
Epidemiology and clinical features of gastroenteritis in hospitalised children: prospective survey during a 2-year period in a Parisian hospital, France
}

M. Lorrot, F. Bon, M. J. El Hajje, S. Aho, M. Wolfer, H. Giraudon, J. Kaplon, E. Marc, Jean Raymond, P. Lebon, et al.

\section{To cite this version:}

M. Lorrot, F. Bon, M. J. El Hajje, S. Aho, M. Wolfer, et al.. Epidemiology and clinical features of gastroenteritis in hospitalised children: prospective survey during a 2-year period in a Parisian hospital, France. European Journal of Clinical Microbiology and Infectious Diseases, 2010, 30 (3), pp.361-368. 10.1007/s10096-010-1094-9 . hal-00647887

\section{HAL Id: hal-00647887 \\ https://hal.science/hal-00647887}

Submitted on 3 Dec 2011

HAL is a multi-disciplinary open access archive for the deposit and dissemination of scientific research documents, whether they are published or not. The documents may come from teaching and research institutions in France or abroad, or from public or private research centers.
L'archive ouverte pluridisciplinaire HAL, est destinée au dépôt et à la diffusion de documents scientifiques de niveau recherche, publiés ou non, émanant des établissements d'enseignement et de recherche français ou étrangers, des laboratoires publics ou privés. 


\section{Epidemiology and clinical features of gastroenteritis in hospitalized children. Prospective survey during a two-year period in a Parisian hospital, France}

Mathie Lorrot, $\mathrm{MD}, \mathrm{PhD}^{1,3 *}$, Fabienne Bon, $\mathrm{PhD}^{2}$, Marie-Joëlle. El-Hajje, $\mathrm{MD}^{3}$, Serge Aho, $\mathrm{MD}^{2}$, Marjorie Wolfer, $\mathrm{MD}^{3}$, Hélène Giraudon, BS ${ }^{2}$, Jérôme Kaplon, BS ${ }^{2}$, Elisabeth Marc,

$\mathrm{MD},{ }^{3,4}$, Josette Raymond, $\mathrm{MD}^{5}$, Pierre Lebon, $\mathrm{MD}, \mathrm{PhD}^{5}$, Pierre Pothier, $\mathrm{MD}, \mathrm{PhD}^{2}$, Dominique Gendrel, $\mathrm{MD}^{3}$.

Service de Pédiatrie, Faculté de Médecine Paris VII, CHU Robert Debré, Paris ${ }^{1}$; Laboratoire de Virologie, CNR des Virus Entériques, CHU de Dijon, Dijon², Service de Pédiatrie, Faculté de Médecine Paris V, CHU Cochin-Saint Vincent de Paul, Paris ${ }^{3}$; Service des Urgences Pédiatriques, Faculté de Médecine Paris XI, CHU Bicêtre, Le Kremlin-Bicêtre ${ }^{4}$; Laboratoire de Microbiologie, Faculté de Médecine Paris V, CHU Cochin-Saint Vincent de Paul, Paris; France.

*Corresponding author :

Dr Mathie Lorrot, Service de Pédiatrie Générale du Pr Faye, Faculté de Médecine Paris VII, Hôpital Robert Debré, Boulevard Sérurier, 75019 Paris-France.

Phone : 33140035361

Fax : 33140034745

E-mail: $\underline{\text { mathie.lorrot@ rdb.aphp.fr }}$

Keywords: gastroenteritis, rotavirus, norovirus, enteric bacteria, clinical severity,

Abbreviated title: Clinical severity of gastroenteritis in hospitalized children

Running head: Viral gastroenteritis severity in children 


\section{Purpose:}

\section{Abstract}

Rotavirus is recognized as the most important agent of severe acute gastroenteritis in young children. In a two-year prospective survey, we investigated the epidemiology and clinical features of the viral and bacterial pathogens in children hospitalized for acute gastroenteritis.

\section{Methods:}

The study was performed in a Parisian teaching hospital from November 2001 to May 2004. Clinical data were prospectively collected to assess the gastroenteritis severity (20-point Vesikari severity score, the need for intravenous rehydration, duration of hospitalization). Stools were systematically tested for group A rotavirus, norovirus, astrovirus and adenovirus 40/41, sapovirus and Aïchi virus and enteropathogenic bacteria.

\section{Results:}

457 children (mean age 15.9 months) were enrolled. Viruses were detected in 305 cases $(66.7 \%)$ and bacteria in 31 cases $(6.8 \%)$. Rotaviruses were the most frequent pathogen (48.8\%) followed by noroviruses (8.3\%) and adenoviruses, astroviruses, Aïchi viruses and sapoviruses respectively in $3.5 \%, 1.5 \%, 0.9 \%$ and $0.4 \%$. Cases of rotavirus gastroenteritis were significantly more severe than those of norovirus with respect to the Vesikari score, duration of hospitalization and the need for intravenous rehydration.

\section{Conclusion:}

Rotaviruses were the most frequent and most severe cause in children hospitalized for acute gastroenteritis, noroviruses also account for a large number of cases in this population. 
Acute gastroenteritis (AGE) is one of the most common diseases in humans, and continues to be a cause of high morbidity and mortality in children worldwide. Children under 5 years of age are particularly prone, and it is calculated that, in this group, there are more than 700 million cases of acute diarrhoea every year [1]. Worldwide estimates indicate a mean of between 3.5 and 7 episodes of diarrhoea during the first 2 years of life, and over 11000 deaths per day throughout the world, particularly in developing countries [2]. In developed countries, deaths from diarrhoea are less common, but AGE is a major cause of morbidity in childhood, leading to many hospitalizations and doctor's visits [3-5].

Much of the gastroenteritis in children is caused by viruses. Group A rotaviruses are the leading cause of severe acute gastroenteritis in infants and children throughout the world, causing an estimated 500,000 - 600,000 deaths each year. All children are infected by the age of 2-3 years and the first infection can usually be associated with acute diarrhoea, which can be severe. Other viral agents of AGE are enteric adenoviruses, caliciviruses and astroviruses. With the improvements in molecular methods of viral diagnosis over the past decade, the role of noroviruses in the etiology of childhood diarrhoea is increasingly recognized. In contrast, the role of Aichi viruses, which belong to the picornavirus family, is not well known $[6,7]$.

To date, there are few data available about the enteric viruses and bacteria in circulation in France. The prevalence and diversity of the four major viruses (rotaviruses, caliciviruses, astroviruses and adenoviruses) are documented for gastroenteritis in children consulting a physician or a hospital emergency service [8-10]. In contrast, their role in communityacquired severe AGE requiring hospitalization have rarely been investigated [11]. The first study of hospitalized gastroenteritis conducted in Saint Vincent de Paul children's hospital (Paris) from January 1997 to December 2000 reported that 50.89\% of 725 children hospitalized for AGE were infected with rotavirus. The role of other viral pathogens was not investigated [12].

We have conducted a prospective study to determine the viral and bacterial etiology of AGE in children hospitalized for AGE. In collaboration with the National Reference Center (NRC) of enteric viruses based in Dijon, we systematically searched for viral pathogens (rotavirus, norovirus, sapovirus, astrovirus, enteric adenovirus and Aichi virus) using sensitive molecular methods. Bacterial pathogens (Salmonella, Shigella and Camplylobacter spp.) were also systematically screened for. We investigated the clinical pattern of the disease in these 
children and the severity of the episodes of AGE. This study provides precise data on the frequency and the severity of bacterial and viral pathogens among children hospitalized for AGE in a Parisian paediatric hospital during a 2-year period.

\section{Patients and methods.}

\section{Population, clinical definitions and specimen collection.}

The study was carried out in the Parisian teaching hospital Cochin- Saint Vincent de Paul, which is situated at the south of Paris and provides easy access to appropriate medical care. At this hospital, there are a mean of 23,000 consultations for all causes in children every year; 15 to $20 \%$ of the consultations for diarrhoea lead to hospitalization [12].

After its approval by the Ethics Committee of the Cochin-Paris V Faculty of medicine, the study was prospectively performed between November 2001 and May 2004 and included all children between 0 months and 15 years of age hospitalized with acute diarrhoea. Acute diarrhoea was defined as at least 3 looser-than normal stools within a 24-h period. All admissions to the hospital were based on clinical examinations at the request of the hospital emergency team. Patients with chronic diarrhoea (> 10 days) were excluded. For each child, clinical data including, age, sex and admission date were prospectively collected at inclusion. Each episode was graded using the 20-point severity score scale [13, 14]. Furthermore, the occurrence of bloody diarrhoea, the use of intravenous rehydration and the length of hospitalization were documented. Stool samples were systematically collected to screen for etiologic agents of diarrhoea. Bacteria (Salmonella, Shigella and Campylobacter spp.) were detected by routine cultivation in the Bacteriology Laboratory of the Saint Vincent de Paul Hospital. After collection, the samples were stored frozen $\left(-20^{\circ} \mathrm{C}\right)$ at the Virology Laboratory. The stools were sent together to the enteric viruses NRC (Dijon), for viral investigation.

\section{Laboratory methods.}

The presence of pathogenic bacteria was determined by routine culture assays on selective media. Stool samples were screened for the presence of group A rotaviruses, adenovirus types 40 and 41 and astroviruses by commercial enzyme immunoassay (EIA) kits (respectively: Biomérieux, France; Oxoïd Ltd, UK; Meridian Diagnostics Inc, USA). All positive samples 
were confirmed and characterized by molecular biology methods (PCR or RT-PCR). Noroviruses, sapoviruses and Aichi virus were detected by RT-PCR.

Nucleic acids were extracted from $20 \%$ stool suspensions in phosphate-buffered saline with a QIA Amp viral RNA kit (Qiagen, Hilden, Germany). The Rotavirus RT-PCR used the primer sets Beg9/End9 [15] and Con2/Con3 [16], The astrovirus RT-PCR used the primers Mon 244 and Mon 245 [17] and the adenovirus PCR used the primers Hex1DEG/Hex2DEG [18]. The norovirus and sapovirus RT-PCR used primer sets in separate reactions. The primer sets SR80/NVP110 [19] and JV12/JV13 [20] were used to amplify a fragment of the RNA polymerase gene of sapoviruses and noroviruses, respectively. The primer sets G1SKF/G1SKR and G2SKF/G2SKR [21] were used to amplify a fragment of the capsid gene of genogroup I and II noroviruses, respectively. The Aichi virus RT-PCR used the primers Ai6261/6779 targeting the RNA polymerase gene [22].

Genotyping of norovirus, sapovirus, astrovirus and Aichi virus was performed by direct sequencing of the PCR products using the ABI Prism Big Dye Terminator Cycle Sequencing Ready Reaction Kit and an automated sequencer (model 373A DNA sequencing system, Applied Biosystems).

\section{Statistical methods.}

Statistical analysis was performed with the Mann-Whitney U test, which was used to compare the medians of clinical symptoms scores in associated rotavirus and norovirus cases. For comparison of proportions, chi-square or Fisher's exact test was used. All tests were twotailed and considered significant when the $\mathrm{P}$ value was $\leq 0.05$.

\section{Results}

\section{Study population and general screening.}

A total of 552 children were hospitalized for gastroenteritis between November 2001 and May 2004. Clinical data and stool samples were obtained from 457 (82.8\%) children. The mean age of these children was 15.9 months (standard deviation, 22.13; range, 0.2 -156 months) and the median was 9.25 months. The sex ratio was 1.26. The mean Vesikari score was 11.7 (standard deviation, 3.16; range, 4-19). Among the 95 sets of data rejected in this study, 13 were rejected for the lack of clinical data and 82 for the absence of a faecal sample. Comparison of the data of patients at the time of enrolment showed that there was no 
significant difference between the data (mean age, sex ratio and Vesikari score) of included and excluded cases ( $\mathrm{p}>0.05$, Mann-Whitney U-test), (data not shown).

Laboratory investigations detected at least one pathogen (virus and/or bacteria) in 330 stool samples $(72.2 \%)$ of the 457 . Viral pathogens were detected in $305(66.7 \%)$ samples, and bacterial pathogens in $31(6.8 \%)$ samples.

Among the viruses, group A rotaviruses were detected in 240 samples (223 in single infections, 17 in mixed infection) and the most prevalent G type were G1 (114 isolates, 47.5\%), G4 (38 isolates, 15.8\%), G3 (38 isolates, 15.8\%), G9 (6 isolates, 2.5\%) and G2 (6 isolates, $2.5 \%$ ). The $\mathrm{P}[8]$ type was by far the most frequent accounting for 233 rotaviruses strains (97\% of rotaviruses strains). The second most frequent group of viruses was norovirus with 55 isolates (38 in single infections and 17 in mixed infections). Molecular characterization showed that genogroup II (GGII) strains were clearly predominant with 50 isolates (90.9\%) including 28 GGII.4 (50.9\%), 18 GGIIb (32.7\%), 3 GGII.2 (5.5\%) and 1 GGII.7 (1.8\%). The remaining 5 noroviruses belonged to the GGI (genotypes 1, 2, 4 and 6). The other viruses were less frequency detected: enteric adenoviruses were detected in 16 samples, $(3.5 \%)$, astrovirus in $7(1.5 \%)$, Aichi in 4 samples $(0.9 \%)$ and sapovirus in 2 samples (0.4\%). Bacterial pathogens were 13 Campylobacter, 14 non typhi Salmonella, 5 Shigella.

Single pathogen infections were responsible for 307 cases of gastroenteritis, most of which were viral agents (283 samples versus 25 samples (24: 1 bacterium; 1: 2 bacteria) for bacteria). Among these, rotaviruses were responsible for 223 cases (48.8\%) and noroviruses for 38 cases $(8.3 \%)$. The other enteric viruses were adenovirus type 40/41, astrovirus, Aïchi virus and sapovirus respectively in 16, 3, 2 and 1 cases. Single bacterial pathogens were found in 24 cases (12 Campylobacter, 9 non typhi Salmonella sp., 3 Shigella).

Mixed infections were detected in 23 samples and mainly involved combinations of viruses (16 samples) especially rotavirus and norovirus. Dual infections with rotavirus and norovirus were detected in 10 samples, with norovirus and astrovirus or sapovirus in 1 sample, with rotavirus and astrovirus or Aïchi virus in 1 sample. Triple infections with norovirus, rotavirus and astrovirus were detected in 2 samples. Mixed infections involving viruses and bacteria were detected in 6 samples: non typhi Salmonella was associated with rotavirus in 2 samples, with norovirus in 1 sample and with norovirus-rotavirus in 1 sample; Campylobacter was 
associated with norovirus and Shigella with Aïchi virus in 1 sample. There was only one dual bacterial infection, which associated Salmonella and Shigella (Table 1).

\section{Monthly distribution.}

The peak of the gastroenteritis epidemic was due to rotavirus and was observed during the winter months, the highest peak occurred in January. Interestingly, a second lower peak of rotavirus incidence was observed in September. Rotaviruses continued to be detected in the interepidemic season but, during these 2 years of surveillance, rotaviruses were not detected in June

Norovirus AGE have a seasonal pattern similar to that of rotavirus AGE with a main peak observed in January and a second peak in September (Figure 1). No consistent seasonal pattern was observed for enteric adenovirus, astrovirus and bacterial AGE.

\section{Etiology of hospitalized AGE in relation to age of the children.}

The proportion of the pathogens detected among children in different age groups is presented in Table 1.

Most hospitalizations for AGE were reported in children less than 2 years of age (385 children, 84.2\%). In these children, $267(69.3 \%)$ had a viral etiology: rotavirus and norovirus were detected in $210(54.5 \%)$ and $47(12.2 \%)$ stool samples, respectively; a single bacterial etiology was identified in 14 stool samples (3.6\%) and mixed bacterial and viral infections in 5 stool samples (1.3\%). In 99 cases of AGE (25.7\%), no acknowledged pathogen was identified.

One hundred and seventy-seven hospitalized children (38.7\%) were less than 6 months of age. In these children, 97 (54.8\%) had a viral etiology: rotavirus and norovirus were detected in 77 $(42.4 \%)$ and $15(8.5 \%)$ stool samples respectively. Single bacterial etiology was identified in 8 stool samples (4.5\%) and mixed bacterial and viral infections in 2 stool samples (1.1\%). In 67 cases of AGE (37.8\%), no acknowledged pathogen was identified.

\section{Clinical severity criteria in children hospitalized for rotavirus or norovirus AGE.}

The clinical severity of the disease was analyzed in children infected by a single virus (rotavirus or norovirus). The 223 children infected with rotavirus and the 38 children infected with norovirus were similar in terms of age and sex ratio ( $p>0.05$, Mann-Whitney U-test). The mean age was 13.65 months (median: 9 months) for rotavirus infections versus 14.9 
months (median: 9.5 months) for norovirus infections. The sex ratio was 1.27 for rotavirus infections versus 1.23 for norovirus infections.

The correlation between the severity of the AGE (severity score, intravenous rehydration, length of hospitalization) and the virus (rotavirus and norovirus) is reported in table 2.

Rotavirus AGE were more severe in infants above 6 months than in infants from 0 to 6 months $(\mathrm{p}<0.0001)$. Rotavirus AGE were significantly more severe than norovirus AGE with respect to the Vesikari score (12.6 versus 10.47, $\mathrm{p}<0.001$ ), the duration of the hospitalizations (3.2 days versus $1.85, \mathrm{p}<0.001)$ and the requirement for intravenous rehydration $(77.13 \%$ versus $55.26 \%, \mathrm{p}=0.005$ ). This contrast was more marked in children above 6 months ( $p<0.007$ for severity score and $p<0.001$ for the length of hospitalization and $p=0.03$ for the need for intravenous rehydration).

These differences in severity according to age were not observed in norovirus gastroenteritis. 


\section{DISCUSSION}

This is the first prospective study to provide data for cause-specific hospitalizations due to community acquired gastroenteritis in children in France. This study was conducted from November 2001 to May 2004 in a Parisian paediatric hospital, but these results are still relevant today. The management of acute gastroenteritis is currently the same with use of an oral rehydration solution and/or intravenous fluid replacement; the trends of hospitalization should continue to show the same pattern. The two rotavirus vaccines (RotaTeq and Rotarix) were licensed in France in 2006, but rotavirus vaccination is not included in the French official recommendations for childhood immunizations, and vaccine coverage is still very low, less than 10 percent.

Our results show that group A rotavirus caused more than $50 \%$ of the total hospitalizations for gastroenteritis per year in a paediatric unit in Paris (France) and was the leading cause of severe diarrhoea in young children. In addition, they highlight the role of norovirus in France as the second viral etiologic agent causing $12 \%$ of hospitalizations for AGE in children. In contrast, the other enteric viruses including adenovirus type 40 and 41 , astrovirus, sapovirus and Aichi virus were a minor cause of hospitalization for childhood gastroenteritis. Altogether, our results show that viruses are by far the most frequent etiology in children hospitalized for gastroenteritis $(66.7 \%)$, whereas a bacterial etiology was found in $6.8 \%$ of cases, and the etiology of $27.8 \%$ of the AGE was not elucidated.

Previous studies underlined the importance of viruses in children hospitalized for gastroenteritis especially in developed countries [23, 24]. However, few studies have investigated prospectively the relative contributions of the different enteric viruses and bacteria in children admitted to hospital for gastroenteritis in developed countries. In accordance with our results, studies conducted in other developed countries in hospitalized children found a large predominance of viruses (56 to $70 \%$ ) versus bacteria (4 to 17\%) [25, 26]. A large retrospective study conducted in Australia found the same ratio between viral and bacterial etiologies in children [27]. In contradiction with these studies, Boga et al [28] in a study conducted in Asturias found bacteria and viruses with a similar frequency, Campylobacter jejuni and Salmonella spp were respectively the second and third main cause of gastroenteritis in children. Among the bacterial etiologies, we also found a large predominance of $C$. jejuni and Salmonella spp, but, on the whole, bacteria were a minor cause of hospitalization for diarrhoea in children. 
Among the viruses, rotaviruses were by far the main cause of gastroenteritis in hospitalized children, far ahead of noroviruses, which were found in $8-15 \%$ of children hospitalized for gastroenteritis [8, 25, 29-31]. These studies and our results contrast with other sentinel studies conducted by physicians in the general population $[5,7,10]$, in which the incidence of norovirus ranged from 10 to $20 \%$. This is close to and in some cases even higher than the incidence of rotavirus infections [10]. One possible explanation of the relatively higher incidence of norovirus is that these sentinel studies highlight the diagnosis of mild infections, whereas more severe cases of gastroenteritis are admitted to the emergency department of the hospital.

Sequence typing of the rotavirus strains showed that the main type was G1;P[8] $(47.5 \%)$ followed by the two other conventional types: G3;P[8] (15.8\%) and G4;P[8] (15.8\%) whereas the G9;P[8] type was seldom detected $(2.5 \%)$. This pattern of genotype distribution with the low prevalence of the G9 type was close to that reported in our previous works since 1995 [8, 10], but considerably different from that we reported during the 2004/2005 season following the present study. In this latter season, G9;P[8] emerged as by far the major genotype $(54.7 \%)$ whereas $\mathrm{G} 1 ; \mathrm{P}[8]$ was very rarely detected [32].

Among noroviruses, there was a clear predominance of genogroup II, and especially the GGII.4 genotype, which is currently reported in adult gastroenteritis outbreaks [33]. Norovirus genotype GII.4 has also been reported as the main norovirus genotype in sporadic cases of gastroenteritis in children [9, 25, 28]. In accordance with these previous reports, our results show that norovirus GGII.4 was predominantly detected in the faeces of children. GGII.4 norovirus was observed throughout the study with a peak during the winter of 2002/2003. It is important to note that this peak corresponded to an increase in gastroenteritis outbreaks throughout Europe caused by a new variant (HU/NoV/Farmington Hill/2002/USA, accession number AY502023)[34, 35]. The second most frequent norovirus genotype found in this study was GGII.b. Several studies have reported this genotype as a cause of sporadic and outbreak cases of gastroenteritits in children, and some of these studies suggested that GGIIb was closely associated with infections in children [36-40]. In this study, the highest rates of GGIIb detection were observed in January-February 2002 and the fall and winter of 2003-2004. These periods coincide with GGIIb adult outbreaks in France [41]. So, the rate of detection of GGIIb and GGII.4 norovirus strains identified in children are similar to those circulating in the adult population in the same period. These results and more recent data (data 
not shown) do not support the hypothesis that one of these strains could play a predominant role in children.

The severity of norovirus and rotavirus gastroenteritis excluded mixed infections and was evaluated on three criteria, the severity score defined by Vesikari [13], the need for intravenous rehydration and the length of the hospitalization. In the population of children studied, norovirus infections were significantly less severe than rotavirus infections. The literature concerning symptom severity in norovirus and rotavirus gastroenteritis is heterogeneous [42]. A number of previous studies found lower levels of disease severity in norovirus than in rotavirus gastroenteritis, and most of these were carried out in developed countries [7, 43-47]. In contrast, other studies found no significant differences between the severity of rotavirus and norovirus infections [48-51]. One such study was conducted by us in Tunisia, and we attributed the severity of the norovirus infection to a lack of medical care at home and the delay to hospitalization for children infected with norovirus. This could also be the case for the studies conducted in countries with poor sanitation and hygiene.

In conclusion, these results highlight the main role of rotavirus in hospitalized gastroenteritis among French children less than 2 years of age. During the study until the end of the 20032004 winter season the G1;P[8] genotype was widespread while G9:P[8] remained rare. A majority of severe rotavirus gastroenteritis requiring hospitalization may be prevented by the widespread use of rotavirus vaccines [52-54]. Noroviruses are the second leading causative agent of gastroenteritis in hospitalized young children and such infections are less severe than those caused by rotavirus. The norovirus genotype pattern in children shows a clear predominance of genotype GII.4 followed by genotype GGIIb. This pattern reflects the norovirus genotypes in circulation within the population rather than a predominance of particular genotypes in children.

\section{Acknowledgments}

We thank Philip Bastable for editorial assistance.

This work was supported by the national PHRC 2001 (Programme Hospitalier de Recherche Clinique) from AP-HP (Assistance Publique - Hôpitaux de Paris).

We thank the physicians and their patients for participation in this study.

\section{References}


[1] Snyder JD, Merson MH (1982) The magnitude of the global problem of acute diarrhoeal disease: a review of active surveillance data. Bull World Health Organ 60 (4):605613

[2] Kapikian AZ (1996) Overview of viral gastroenteritis. Arch Virol Suppl 12:7-19

[3] Parashar UD, Hummelman EG, Bresee JS, Miller MA, Glass RI (2003) Global illness and deaths caused by rotavirus disease in children. Emerg Infect Dis 9 (5):565-572

[4] Glass RI, Kilgore PE, Holman RC, Jin S, Smith JC, Woods PA, Clarke MJ, Ho MS, Gentsch JR (1996) The epidemiology of rotavirus diarrhea in the United States: surveillance and estimates of disease burden. J Infect Dis 174 Suppl 1:S5-11

[5] de Wit MA, Koopmans MP, Kortbeek LM, van Leeuwen NJ, Vinje J, van Duynhoven YT (2001) Etiology of gastroenteritis in sentinel general practices in the netherlands. Clin Infect Dis 33 (3):280-288

[6] Ambert-Balay K, Lorrot M, Bon F, Giraudon H, Kaplon J, Wolfer M, Lebon P, Gendrel D, Pothier P (2008) Prevalence and genetic diversity of Aichi virus strains in stool samples from community and hospitalized patients. J Clin Microbiol 46 (4):1252-1258

[7] Pang XL, Honma S, Nakata S, Vesikari T (2000) Human caliciviruses in acute gastroenteritis of young children in the community. J Infect Dis 181 Suppl 2:S288-294

[8] Bon F, Fascia P, Dauvergne M, Tenenbaum D, Planson H, Petion AM, Pothier P, Kohli E (1999) Prevalence of group A rotavirus, human calicivirus, astrovirus, and adenovirus type 40 and 41 infections among children with acute gastroenteritis in Dijon, France. J Clin Microbiol 37 (9):3055-3058

[9] Buesa J, Collado B, Lopez-Andujar P, Abu-Mallouh R, Rodriguez Diaz J, Garcia Diaz A, Prat J, Guix S, Llovet T, Prats G, Bosch A (2002) Molecular epidemiology of caliciviruses causing outbreaks and sporadic cases of acute gastroenteritis in Spain. J Clin Microbiol 40 (8):2854-2859

[10] Chikhi-Brachet R, Bon F, Toubiana L, Pothier P, Nicolas JC, Flahault A, Kohli E (2002) Virus diversity in a winter epidemic of acute diarrhea in France. J Clin Microbiol 40 (11):4266-4272

[11] Kapikian AZ (2001) A rotavirus vaccine for prevention of severe diarrhoea of infants and young children: development, utilization and withdrawal. Novartis Found Symp 238:153171; discussion 171-159

[12] Moulin F, Marc E, Lorrot M, Coquery S, Sauve-Martin H, Ravilly S, Lebon P, Raymond J, Brunet F, Gendrel D (2002) [Hospitalization for acute community-acquired rotavirus gastroenteritis: a 4-year survey]. Arch Pediatr 9 (3):255-261

[13] Ruuska T, Vesikari T (1990) Rotavirus disease in Finnish children: use of numerical scores for clinical severity of diarrhoeal episodes. Scand J Infect Dis 22 (3):259-267

[14] Joensuu J, Koskenniemi E, Pang XL, Vesikari T (1997) Randomised placebocontrolled trial of rhesus-human reassortant rotavirus vaccine for prevention of severe rotavirus gastroenteritis. Lancet 350 (9086):1205-1209

[15] Gouvea V, Glass RI, Woods P, Taniguchi K, Clark HF, Forrester B, Fang ZY (1990) Polymerase chain reaction amplification and typing of rotavirus nucleic acid from stool specimens. J Clin Microbiol 28 (2):276-282

[16] Gentsch JR, Glass RI, Woods P, Gouvea V, Gorziglia M, Flores J, Das BK, Bhan MK (1992) Identification of group A rotavirus gene 4 types by polymerase chain reaction. J Clin Microbiol 30 (6):1365-1373

[17] Noel JS, Lee TW, Kurtz JB, Glass RI, Monroe SS (1995) Typing of human astroviruses from clinical isolates by enzyme immunoassay and nucleotide sequencing. J Clin Microbiol 33 (4):797-801 
[18] Allard A, Albinsson B, Wadell G (2001) Rapid typing of human adenoviruses by a general PCR combined with restriction endonuclease analysis. J Clin Microbiol 39 (2):498505

[19] Noel JS, Liu BL, Humphrey CD, Rodriguez EM, Lambden PR, Clarke IN, Dwyer DM, Ando T, Glass RI, Monroe SS (1997) Parkville virus: a novel genetic variant of human calicivirus in the Sapporo virus clade, associated with an outbreak of gastroenteritis in adults. J Med Virol 52 (2):173-178

[20] Vinje J, Koopmans MP (1996) Molecular detection and epidemiology of small roundstructured viruses in outbreaks of gastroenteritis in the Netherlands. J Infect Dis 174 (3):610615

[21] Kojima S, Kageyama T, Fukushi S, Hoshino FB, Shinohara M, Uchida K, Natori K, Takeda N, Katayama K (2002) Genogroup-specific PCR primers for detection of Norwalklike viruses. J Virol Methods 100 (1-2):107-114

[22] Yamashita T, Sugiyama M, Tsuzuki H, Sakae K, Suzuki Y, Miyazaki Y (2000) Application of a reverse transcription-PCR for identification and differentiation of Aichi virus, a new member of the Picornavirus family associated with gastroenteritis in humans. J Clin Microbiol 38 (8):2955-2961

[23] Clark B, McKendrick M (2004) A review of viral gastroenteritis. Curr Opin Infect Dis 17 (5):461-469

[24] Parashar UD, Gibson CJ, Bresse JS, Glass RI (2006) Rotavirus and severe childhood diarrhea. Emerg Infect Dis 12 (2):304-306

[25] Kirkwood CD, Clark R, Bogdanovic-Sakran N, Bishop RF (2005) A 5-year study of the prevalence and genetic diversity of human caliciviruses associated with sporadic cases of acute gastroenteritis in young children admitted to hospital in Melbourne, Australia (19982002). J Med Virol 77 (1):96-101

[26] Ambrozova H, Schramlova J (2005) [Viral gastroenteritis in children]. Klin Mikrobiol Infekc Lek 11 (3):83-91

[27] Barnes GL, Uren E, Stevens KB, Bishop RF (1998) Etiology of acute gastroenteritis in hospitalized children in Melbourne, Australia, from April 1980 to March 1993. J Clin Microbiol 36 (1):133-138

[28] Boga JA, Melon S, Nicieza I, De Diego I, Villar M, Parra F, De Ona M (2004) Etiology of sporadic cases of pediatric acute gastroenteritis in asturias, Spain, and genotyping and characterization of norovirus strains involved. J Clin Microbiol 42 (6):2668-2674

[29] Oh DY, Gaedicke G, Schreier E (2003) Viral agents of acute gastroenteritis in German children: prevalence and molecular diversity. J Med Virol 71 (1):82-93

[30] O'Ryan ML, Mamani N, Gaggero A, Avendano LF, Prieto S, Pena A, Jiang X, Matson DO (2000) Human caliciviruses are a significant pathogen of acute sporadic diarrhea in children of Santiago, Chile. J Infect Dis 182 (5):1519-1522

[31] Simpson R, Aliyu S, Iturriza-Gomara M, Desselberger U, Gray J (2003) Infantile viral gastroenteritis: on the way to closing the diagnostic gap. J Med Virol 70 (2):258-262

[32] de Rougemont A, Kaplon J, Lebon P, Huet F, Denis F, Alain S, Fourcade L, Grosjean J, El-Hajje MJ, Gendrel D, Pothier P (2009) Unexpected substitution of dominant rotavirus G genotypes in French hospitalized children over five consecutive seasons. Eur J Clin Microbiol Infect Dis 28 (4):403-407

[33] Kroneman A, Harris J, Vennema H, Duizer E, van Duynhoven Y, Gray J, Iturriza M, Bottiger B, Falkenhorst G, Johnsen C, von Bonsdorff CH, Maunula L, Kuusi M, Pothier P, Gallay A, Schreier E, Koch J, Szucs G, Reuter G, Krisztalovics K, Lynch M, McKeown P, Foley B, Coughlan S, Ruggeri FM, Di Bartolo I, Vainio K, Isakbaeva E, Poljsak-Prijatelj M, Grom AH, Bosch A, Buesa J, Fauquier AS, Hernandez-Pezzi G, Hedlund KO, Koopmans M 
(2008) Data quality of 5 years of central norovirus outbreak reporting in the European Network for food-borne viruses. J Public Health (Oxf) 30 (1):82-90

[34] Lopman B, Vennema H, Kohli E, Pothier P, Sanchez A, Negredo A, Buesa J, Schreier E, Reacher M, Brown D, Gray J, Iturriza M, Gallimore C, Bottiger B, Hedlund KO, Torven M, von Bonsdorff CH, Maunula L, Poljsak-Prijatelj M, Zimsek J, Reuter G, Szucs G, Melegh B, Svennson L, van Duijnhoven Y, Koopmans M (2004) Increase in viral gastroenteritis outbreaks in Europe and epidemic spread of new norovirus variant. Lancet 363 (9410):682688

[35] Zheng DP, Ando T, Fankhauser RL, Beard RS, Glass RI, Monroe SS (2006) Norovirus classification and proposed strain nomenclature. Virology 346 (2):312-323

[36] Liu C, Grillner L, Jonsson K, Linde A, Shen K, Lindell AT, Wirgart BZ, Johansen K (2006) Identification of viral agents associated with diarrhea in young children during a winter season in Beijing, China. J Clin Virol 35 (1):69-72

[37] Rachakonda G, Choudekar A, Parveen S, Bhatnagar S, Patwari A, Broor S (2008) Genetic diversity of noroviruses and sapoviruses in children with acute sporadic gastroenteritis in New Delhi, India. J Clin Virol 43 (1):42-48

[38] Arista S, Giammanco GM, De Grazia S, Ramirez S, Lo Biundo C, Colomba C, Cascio A, Martella V (2006) Heterogeneity and temporal dynamics of evolution of G1 human rotaviruses in a settled population. J Virol 80 (21):10724-10733

[39] Waters V, Ford-Jones EL, Petric M, Fearon M, Corey P, Moineddein R (2000) Etiology of community-acquired pediatric viral diarrhea: a prospective longitudinal study in hospitals, emergency departments, pediatric practices and child care centers during the winter rotavirus outbreak, 1997 to 1998. The Pediatric Rotavirus Epidemiology Study for Immunization Study Group. Pediatr Infect Dis J 19 (9):843-848

[40] Beersma MF, Schutten M, Vennema H, Hartwig NG, Mes TH, Osterhaus AD, van Doornum GJ, Koopmans M (2009) Norovirus in a Dutch tertiary care hospital (2002-2007): frequent nosocomial transmission and dominance of GIIb strains in young children. J Hosp Infect

[41] Bon F, Ambert-Balay K, Giraudon H, Kaplon J, Le Guyader S, Pommepuy M, Gallay A, Vaillant V, de Valk H, Chikhi-Brachet R, Flahaut A, Pothier P, Kohli E (2005) Molecular epidemiology of caliciviruses detected in sporadic and outbreak cases of gastroenteritis in France from December 1998 to February 2004. J Clin Microbiol 43 (9):4659-4664

[42] Patel MM, Widdowson MA, Glass RI, Akazawa K, Vinje J, Parashar UD (2008) Systematic literature review of role of noroviruses in sporadic gastroenteritis. Emerg Infect Dis 14 (8):1224-1231

[43] Iturriza Gomara M, Simpson R, Perault AM, Redpath C, Lorgelly P, Joshi D, Mugford M, Hughes CA, Dalrymple J, Desselberger U, Gray J (2008) Structured surveillance of infantile gastroenteritis in East Anglia, UK: incidence of infection with common viral gastroenteric pathogens. Epidemiol Infect 136 (1):23-33

[44] Chen SY, Chang YC, Lee YS, Chao HC, Tsao KC, Lin TY, Ko TY, Tsai CN, Chiu $\mathrm{CH}$ (2007) Molecular epidemiology and clinical manifestations of viral gastroenteritis in hospitalized pediatric patients in Northern Taiwan. J Clin Microbiol 45 (6):2054-2057

[45] Colomba C, De Grazia S, Giammanco GM, Saporito L, Scarlata F, Titone L, Arista S (2006) Viral gastroenteritis in children hospitalised in Sicily, Italy. Eur J Clin Microbiol Infect Dis 25 (9):570-575

[46] Marie-Cardine A, Gourlain K, Mouterde O, Castignolles N, Hellot MF, Mallet E, Buffet-Janvresse C (2002) Epidemiology of acute viral gastroenteritis in children hospitalized in Rouen, France. Clin Infect Dis 34 (9):1170-1178

[47] Medici MC, Martinelli M, Abelli LA, Ruggeri FM, Di Bartolo I, Arcangeletti MC, Pinardi F, De Conto F, Izzi G, Bernasconi S, Chezzi C, Dettori G (2006) Molecular 
epidemiology of norovirus infections in sporadic cases of viral gastroenteritis among children in Northern Italy. J Med Virol 78 (11):1486-1492

[48] Nakagomi T, Correia JB, Nakagomi O, Montenegro FM, Cuevas LE, Cunliffe NA, Hart CA (2008) Norovirus infection among children with acute gastroenteritis in Recife, Brazil: disease severity is comparable to rotavirus gastroenteritis. Arch Virol 153 (5):957-960 [49] Sakai Y, Nakata S, Honma S, Tatsumi M, Numata-Kinoshita K, Chiba S (2001) Clinical severity of Norwalk virus and Sapporo virus gastroenteritis in children in Hokkaido, Japan. Pediatr Infect Dis J 20 (9):849-853

[50] Nguyen TA, Yagyu F, Okame M, Phan TG, Trinh QD, Yan H, Hoang KT, Cao AT, Le Hoang P, Okitsu S, Ushijima H (2007) Diversity of viruses associated with acute gastroenteritis in children hospitalized with diarrhea in Ho Chi Minh City, Vietnam. J Med Virol 79 (5):582-590

[51] Sdiri-Loulizi K, Gharbi-Khelifi H, de Rougemont A, Chouchane S, Sakly N, AmbertBalay K, Hassine M, Guediche MN, Aouni M, Pothier P (2008) Acute infantile gastroenteritis associated with human enteric viruses in Tunisia. J Clin Microbiol 46 (4):1349-1355

[52] Vesikari T, Matson DO, Dennehy P, Van Damme P, Santosham M, Rodriguez Z, Dallas MJ, Heyse JF, Goveia MG, Black SB, Shinefield HR, Christie CD, Ylitalo S, Itzler RF, Coia ML, Onorato MT, Adeyi BA, Marshall GS, Gothefors L, Campens D, Karvonen A, Watt JP, O'Brien KL, DiNubile MJ, Clark HF, Boslego JW, Offit PA, Heaton PM (2006) Safety and efficacy of a pentavalent human-bovine (WC3) reassortant rotavirus vaccine. N Engl J Med 354 (1):23-33

[53] Boom JA, Tate JE, Sahni LC, Rench MA, Hull JJ, Gentsch JR, Patel MM, Baker CJ, Parashar UD Effectiveness of pentavalent rotavirus vaccine in a large urban population in the United States. Pediatrics 125 (2):e199-207

[54] Ruiz-Palacios GM, Perez-Schael I, Velazquez FR, Abate H, Breuer T, Clemens SC, Cheuvart B, Espinoza F, Gillard P, Innis BL, Cervantes Y, Linhares AC, Lopez P, MaciasParra M, Ortega-Barria E, Richardson V, Rivera-Medina DM, Rivera L, Salinas B, Pavia-Ruz N, Salmeron J, Ruttimann R, Tinoco JC, Rubio P, Nunez E, Guerrero ML, Yarzabal JP, Damaso S, Tornieporth N, Saez-Llorens X, Vergara RF, Vesikari T, Bouckenooghe A, Clemens R, De Vos B, O'Ryan M (2006) Safety and efficacy of an attenuated vaccine against severe rotavirus gastroenteritis. N Engl J Med 354 (1):11-22 

Table 1: Etiology of gastroenteritis in 457 hospitalized children in relation to age.

\begin{tabular}{|c|c|c|c|c|c|c|}
\hline & \multicolumn{5}{|c|}{ Age (months) } & \multirow[t]{2}{*}{ Total } \\
\hline & $0-6$ & $>6-12$ & $>12-24$ & $>24-60$ & $>60-180$ & \\
\hline Rotavirus & $\begin{array}{l}77 \\
(43.5 \%) \\
\end{array}$ & $\begin{array}{l}63 \\
(59.4 \%) \\
\end{array}$ & $59(57.8 \%)$ & $22(44.9 \%)$ & $4(17.4 \%)$ & $\begin{array}{l}223 \\
(48.8 \%) \\
\end{array}$ \\
\hline Norovirus & $15(8.5 \%)$ & $10(9.4 \%)$ & $8(7.8 \%)$ & $3(6.1 \%)$ & $2(8.7 \%)$ & $38(8.3 \%)$ \\
\hline Adenovirus & 6 & 5 & 5 & 0 & 0 & $16(3.50)$ \\
\hline Astrovirus & 1 & 2 & 0 & 0 & 0 & 3 \\
\hline Aïchivirus & 0 & 0 & 1 & 0 & 1 & 2 \\
\hline Sapovirus & 0 & 0 & 1 & 0 & 0 & 1 \\
\hline Bacteria & 8 & $2^{\mathrm{a}}$ & 4 & 6 & 5 & $\begin{array}{l}25^{\mathrm{a}} \\
(5.4 \%)\end{array}$ \\
\hline $\begin{array}{l}\text { Virus }+ \\
\text { Bacteria }\end{array}$ & $2^{b ; c}$ & 0 & $3^{\mathrm{d} ; \mathrm{e}}$ & $1^{\mathrm{f}}$ & 0 & 6 \\
\hline Virus + virus & $3^{\mathrm{g} ; \mathrm{h} ; \mathrm{i}}$ & $9^{\mathrm{j} ; \mathrm{k} ; 1 ; \mathrm{m}}$ & 4 & 0 & 0 & $16(3.5 \%)$ \\
\hline NPI* & $\begin{array}{l}67(37.8 \\
\%)\end{array}$ & $\begin{array}{l}15(14.1 \\
\%)\end{array}$ & $\begin{array}{l}17(16.7 \\
\%)\end{array}$ & $\begin{array}{l}17(34.7 \\
\%)\end{array}$ & $\begin{array}{l}11(47.8 \\
\%)\end{array}$ & $\begin{array}{l}127(27.8 \\
\%)\end{array}$ \\
\hline Total & $\begin{array}{l}177 \\
(38.7 \%)\end{array}$ & $\begin{array}{l}106 \\
(23.2 \%)\end{array}$ & $\begin{array}{l}102 \\
(22.32 \%)\end{array}$ & $\begin{array}{l}49 \\
(10.72 \%)\end{array}$ & $\begin{array}{l}23 \\
(5.03 \%)\end{array}$ & 457 \\
\hline
\end{tabular}

Values are numbers of cases, with percentages in parentheses.

* NPI: No acknowledged enteric pathogens. 
a : 1 Salmonella + shigella

b : 1 Salmonella + norovirus

c : 1 campylobacter + norovirus

$\mathrm{d}$ : 1 Salmonella + norovirus + rotavirus

e : 2 Salmonella + rotavirus

f: 1 Shigella + Aichi virus

$\mathrm{g}: 1$ norovirus + astrovirus

$\mathrm{h}: 1$ norovirus + rotavirus

i : 1 norovirus + rotavirus

$\mathrm{j}: 2$ norovirus + rotavirus + astrovirus

$\mathrm{k}: 1$ rotavirus + Aichi virus

$1: 1$ rotavirus + astrovirus

$\mathrm{m}: 5$ norovirus + rotavirus 
Table 2: Clinical features according the etiologic agent (rotavirus or norovirus, mixed infections excluded) related to the age of the children with gastroenteritis.

\begin{tabular}{|c|c|c|c|c|c|c|c|c|c|}
\hline \multirow[t]{2}{*}{ Age } & \multicolumn{3}{|c|}{ 0-6 months (177) } & \multicolumn{3}{|c|}{ 6-24 months (208) } & \multicolumn{3}{|c|}{$>24$ months (72) } \\
\hline & $\begin{array}{l}\text { Rotavirus } \\
\quad(75)\end{array}$ & $\begin{array}{l}\text { Norovirus } \\
\text { (15) }\end{array}$ & $p$ value & $\begin{array}{l}\text { Rotavirus } \\
\quad(122)\end{array}$ & $\begin{array}{l}\text { Norovirus } \\
\text { (18) }\end{array}$ & $p$ value & $\begin{array}{l}\text { Rotavirus } \\
\text { (26) }\end{array}$ & $\begin{array}{l}\text { Norovirus } \\
\text { (5) }\end{array}$ & $p$ val \\
\hline $\begin{array}{l}\text { Severity score, } 1-20 \\
\text { points: mean value } \\
(+/-s d)\end{array}$ & $\begin{array}{c}11.1^{\mathrm{a}} \\
(+/-2.89)\end{array}$ & $\begin{array}{c}9.93^{\mathrm{b}} \\
(+/-2.46)\end{array}$ & $N S$ & $\begin{array}{c}13.48^{a} \\
(+/-2.54)\end{array}$ & $\begin{array}{l}11.39^{b} \\
(+/-3.05)\end{array}$ & $p<0.002$ & $\begin{array}{c}12.88^{a} \\
(+/-2.94)\end{array}$ & $\begin{array}{c}8,8^{\mathrm{b}} \\
(+/-2.28)\end{array}$ & $p=0.0$ \\
\hline $\begin{array}{l}\text { Length of } \\
\text { hospitalization in } \\
\text { days }(+/-s d)\end{array}$ & $\begin{array}{c}3.26 \\
(+/-1.84)\end{array}$ & $\begin{array}{c}2.17 \\
(+/-1.06)\end{array}$ & $p=0.0293$ & $\begin{array}{c}2.90 \\
(+/-1.39)\end{array}$ & $\begin{array}{c}1.78 \\
(+/-1.06)\end{array}$ & $p=0.0013$ & $\begin{array}{c}2,85 \\
(+/-1.26)\end{array}$ & $\begin{array}{c}1,2 \\
(+/-0.45)\end{array}$ & $p=0.01$ \\
\hline $\begin{array}{l}\text { Intravenous } \\
\text { rehydration }(\%)\end{array}$ & $\begin{array}{c}40 \\
(53.3 \%)\end{array}$ & $\begin{array}{c}5 \\
(33.33 \%)\end{array}$ & $N S$ & $\begin{array}{c}107 \\
(87.7 \%) \\
\end{array}$ & $\begin{array}{c}12 \\
(66.67 \%) \\
\end{array}$ & $p=0.031$ & $\begin{array}{c}25 \\
(96.1 \%) \\
\end{array}$ & $\begin{array}{c}4 \\
(80 \%) \\
\end{array}$ & $N S$ \\
\hline Bloody stools (\%) & 0 & 0 & & $\begin{array}{c}3 \\
(2.46 \%)\end{array}$ & $\begin{array}{c}2 \\
(11.11 \%)\end{array}$ & & $\begin{array}{c}1 \\
(3.8 \%)\end{array}$ & $\begin{array}{c}0 \\
(0 \%)\end{array}$ & \\
\hline
\end{tabular}

$\mathrm{NS}=$ Not significant

a) Rotavirus severity score: $0-6$ months versus $6-24$ months $(\mathrm{p}<0.0001)$ or $>24$ months $(\mathrm{p}=0.008)$.

b) Norovirus severity score: $\mathrm{p}$ not significant for all age groups. 
Figure 1: Monthly distribution of viruses in children hospitalized for gastroenteritis (January 2002- May 2004)

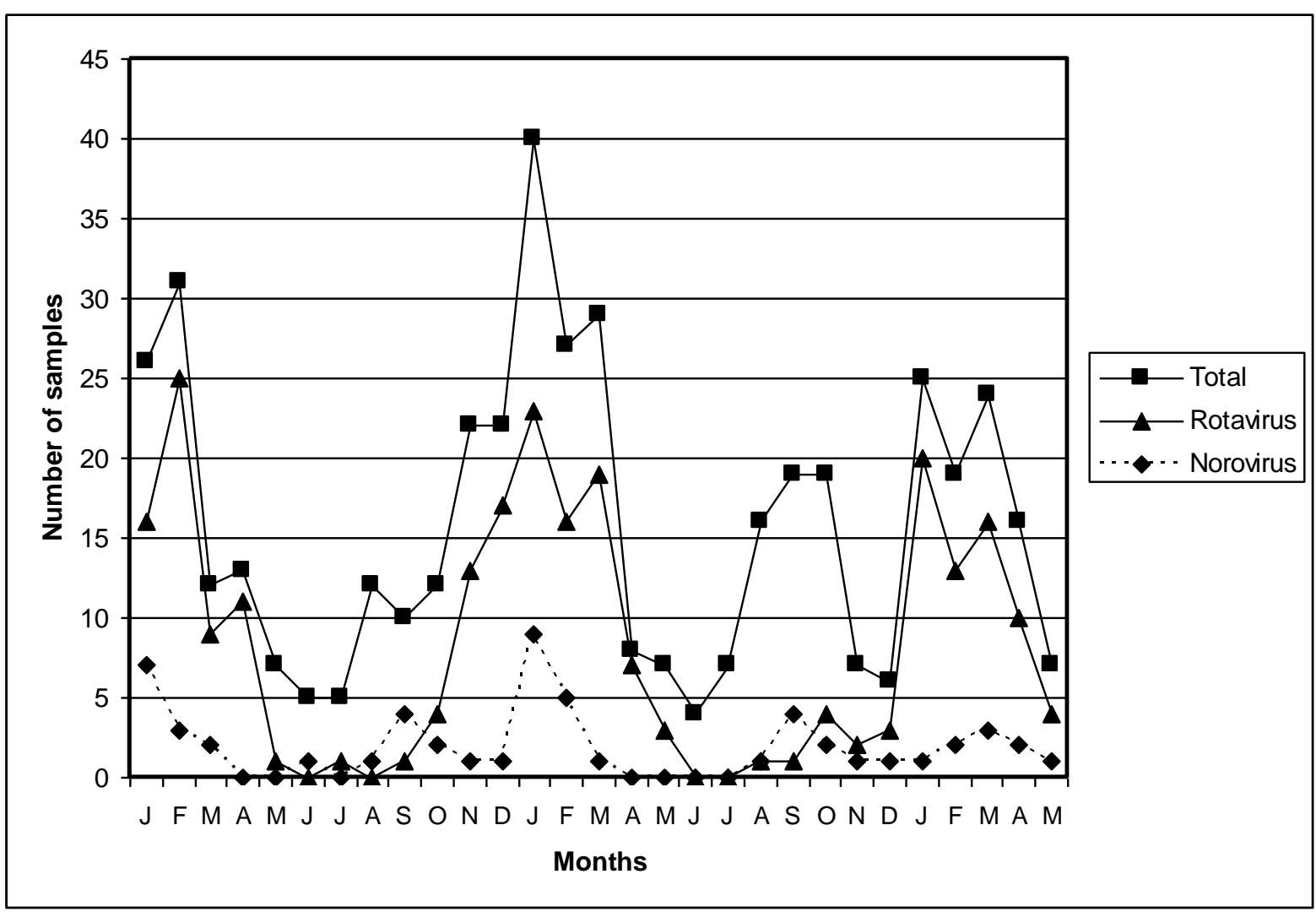

